\title{
Contents, Vol. 10, 1964/65
}

\section{Gerontologia}

Zeitschriftfürexperimentell-biologischeund-medizinischeAlternsforschung-Journal of Experimental Biological and Experimental Medical Research on Ageing - Journal de Recherches expérimentales, biologiques et médicales, sur le vieillissement

Editor :

\section{F. Verzár, Basel}

\section{Coeditores}

\section{F. Bourlière}

D. A. Hall

[ C.M.McCay

Paris

Leeds

Ithaca, N.Y.

Collaboratores :

A. v. Albertini, Zurich

H. Guth, Basel

W. Andrew,

L. Haranghy, Budapest

Indianapolis, Ind.

E. Jalavisto, Helsinki

J. Baló, Budapest

W.J.E.Jessop, Dublin

J. Banga, Budapest

V. R. Khanolkar, Bombay

L. Binet, Paris 
P. S. Krishnan, Lucknow

J. E. Birren, Bethesda,

Md.

P.L. Krohn, Birmingham

G. H. Bourne, Atlanta,

Ga.

P. J. Lindop, London

A. Comfort, London

K. Miescher, Basel

J. Danielli, London

H. Mislin, Mainz

W. Doberauer, Wien

O. Mühlbock, Amsterdam

G. Di Macco, Roma

R. Nicolaysen, Oslo

A. V. Everitt, Sydney

F. Roulet, Basel

K. J. Franklin, London

J. H. Sheldon, Wolverhampton

T. Geill, København

R. E. Tunbridge, Leeds

T. Gillman, Durban

A. L. Vischer, Basel

E. Greppi, Firenze

R. Wagner, München

J. Groen, Jerusalem

A. Welford, Cambridge 1964/65

Vol. 10

BASEL (Schweiz) S. KARGER NEW YORK

Alle Rechte, insbesondere das der Übersetzung in fremde Sprachen, vorbehalten.

Ohne ausdrückliche Genehmigung des Verlages ist es auch nicht gestattet, diesen Band oder Teile daraus auf photomechanischem Wege $£$ Photokopie, Mikrokopie) zu vervielfältigen. (C)

Copyright 1964 by S.Karger AG, Basel

Printed in Switzerland by Buchdruckerei National-Zeitung AG, Basel 
Cliches: Aberegg-Steiner \& Cie. AG, Bern

Index

Allaire, Y.: vide Rapaport, A.

Alvarfz, A. S.: vide Woodford-Williams, E.

Árvay, A. und Takács, I.: Anderung der Thermokontraktion von Kollagen-fasern während der Gravidität. Die Wirkung der Gravidität auf die Geschwindigkeit des biologischen

Alterns von Kollagen 146

Aschheim, P.:

Résultats fournis par la greffe hétérochrone des ovaires dans I'etude de la regulation

hypothalamo-

hypophyso-ovarienne de la ratte senile

65

Behnke, Roy $\mathrm{H}$.

vide Warren, Andrew

Beregi, Edit; Simon, J. and Földes, I.:

Anaphylaxis of Rabbits and Rats of Different Ages 183

Bertolini, A. M.; Quarto di Palo, F. M. and Gastaldi, L.:

Diaphorase I, Catalase and Glucose-6-Phosphate

Dehydrogenase Activity in the Erythrocytes of Aged

Subjects $\quad 167$

Bourlière, F.: vide Rapaport, A.

Caniggia, A.; Gennari, C.; Cesari, L. and Romano, S.:

Intestinal Absorption of $45 \mathrm{Ca}$ in Adult and Old

Human Subjects 193

Cesari, L.:

Chvapil, M. and Deyl, Z.:

Das, B. C.:

Deyl, Z.: Dixon, M. P.: Földes, I.: Gastaldi, L.: Gastaldi, L.: Gennari, C.: Gírard, F.:

vide Caniggia, $\mathrm{A}$.

Some Theoretical Considerations on the Aging of

Collagen (Critical review) 199

Age-Related Trends in the Blood Chemistry and

Hematology of the Indian Carp (Catla catla) ... 47

vide Chvapil, $\mathrm{M}$.

vide Woodford-Williams, E.

vide Beregi, Edit

vide Bertolini, A. M.

vide Quarto di Palo, F. M.

vide Caniggia, A.

vide Rapaport, A.

Goullet, Ph. et Kaufmann, H.:

Etudes ßur la réponse immunitaire selon l'âge chez

le rat 76

Hahn, H. P. von : Age-Related Alterations in the Structure of DNA.

$\Pi$. The Role of Histones 174

Hahn, H. P. von: $\quad$ Analysis of Histones from Thymus of Young and

Old Bo vines by Gel Filtration $\quad 107$ 
Jalavisto, Eeva: On the Interdependence of Circulatory-Respiratory

and Neural-Mental Variables 31

Kanungo, M. S. and Patnaik, B. K.:

Effect of Age on the Uptake of Ascorbic Acid by the

Skin and the Bone of the Rat 155

Kaufmann, H.:vide Goullet, Ph.

Landless, B.: vide Woodford-Williams, E.

Mendoza, S. A. and Milch, R. A.:

Age Variations of Nominal Tensile Strength of

Wistar Rat Skins $\quad 42$

Milch, R. A.: Reaction of Certain Aliphatic Aldehydes with

Gelatin 117

Milch, R. A.: vide Mendoza, S. A.

Mombelli, L. E.: $\quad$ vide Quarto di Palo, F. M.

Patnaik, B. K.: vide Kanungo, M. S.

Quarto di Palo, F. M.; Mombelli, L. E. and Gastaldi, L.:

Age Changes in Phospholipids, RNA and DNA

Content in Tissues of Male White Rats 161

Quarto di Palo, F. M.: vide Bertolini, A. M.

Rapaport, A.; Allaire, Y.; Bourlière, F. et Girard, F.:

Réactivité au «stress» et capacité d'adaptation à une situation inhabituellechezle rat jeune, adulte et âgé 20

Romano, S.: vide Caniggia, A.

Sato, Tsuneko : $\quad$ vide Warren, Andrew

Schaub, M. C.: Changes of Collagen in the Aging and in the Preg

nant Uterus of White Rats 137

Schaub, M. C.: $\quad$ The Aging of Collagen in the Heart Muscle. ... 38

Simon, J.: vide Beregi, Edit

Steinmann, B.: Uber Beziehungen zwischen Cholesterin- und

Fibrinogengehalt, Thromboembolien und Athero-

sklerose $\quad 100$

Takács, I.: $\quad$ vide Árvay, A.

Warren, Andrew; Behnke, Roy H. and Sato, Tsuneko:

Changes with Advancing Age in the Cell Population

of Human Dermis 1

Webster, D.: vide Woodford-Williams, E.

Woodford-Williams, E.; Alvarez, A. S.; Webster, D.; Landless, B. and

Dixon, M. P.: Serum Protein Patterns in "Normal" and Patho

logical Ageing 86

Book Reviews - Buchbespreghungen - Livres Nouveaux 215

Varia 218

Index Rerum ad Vol. 10

219 